\begin{tabular}{|c|c|}
\hline$\sigma_{\infty}^{\infty}$ & $\begin{array}{c}\text { International Journal of Trend in Scientific } \\
\text { Research and Development (IJTSRD) }\end{array}$ \\
\hline $\begin{array}{lll}0 & 0\end{array}$ & International Open Access Journal \\
\hline 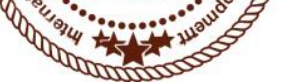 & ISSN No: 2456 - 6470 | www.ijtsrd.com | Volume - 2 | Issue - 1 \\
\hline
\end{tabular}

\title{
A Review Study on Post Implementation of Goods and Service Tax (GST) on Aviation Sector in India
}

\author{
Dr Manish P Parmar \\ Ph.D Coordinator, Sumandeep Vidyapeeth Deemed to \\ be University, Vadodara, Gujarat, India
}

\author{
Mr Cyril Parmar \\ Sr Executive Officer (HR), Amul Dairy, \\ Anand, Gujarat
}

\begin{abstract}
In this paper we focused on the post implementation review on impact of Goods and Service Tax (GST) on aviation sector in India.

Aviation is one of the fastest growing sectors in Indian economy which is extensively used by local as well as the international populace. The government of India has initiated numerous measures like flexible travel proceedings, liberalization and infrastructure development to ensure the traveling safer and more

\section{Introduction:}

India's civil aviation sector is on a high-growth flight. India aims to become the third-largest aviation market by 2026. The Aviation sector has convoyed in a new era of development, determined by various aspects like lower cost of carriers (LCCs), sophisticated airport premises, Foreign Direct Investment (FDI) in domestic sector, advanced IT interface and growing emphasis on regional connectivity.
\end{abstract} expedient. It is, conversely, assumed that the newly implemented taxation, Goods and Service Tax (GST) implemented from the $1^{\text {st }}$ July 2017 have positive as well as negative impacts on the aviation sector of India. However, GST simplified the confusion of multiple taxes and the aggravations that are countenanced due to the indirect taxes imposed by both the State and Central Governments, it is impinged on the airline fares and other areas related to the aviation sector of India.

We conclude that the airline sector hoped to attract a large number of passengers in coming years. In such a situation, implementation of GST might cause a problem for the industry. Increased cost might create pressure for the airlines, and as a result, the growth of the industry might face a difficulty. So the central government should convince state governments to bring down taxes on ATF at the earliest.

Keywords: GST, Aviation, Airline, Service, Tax, Civil, Industry, Impact, MRO, LCCs, FDI, CAGR
According to the IATA, India will become the third largest aviation market in the world in terms of passenger mobility by 2026. In addition, the IATA also expects the growth in air passengers at a compound average growth rate (CAGR) of 3.7 percent to double from 3.8 billion air passengers in 2016 to 7.2 billion air passengers by 2035 .

In recent times, the GST board announced that the rates of Goods and Services Tax applicable on the supply of various goods and services. These rates are distributed across different rate bands of $5 \%, 12 \%$, $18 \%$ and $28 \%$.

Civil Aviation Sector is one of the thriving segments of our economy. Over the last few years the civil aviation industry has witnessed exponential growth under the VAT and Service Tax regime. How the shift of previous taxation to GST affects the growth of the rapidly increasing aviation sector and its impact on airfares? 


\section{GST in Aviation Sector:}

Goods and Services Tax (GST) is an indirect tax modification which aims to remove various tax barriers between states and create one single market. For that to take place the constitution first it needs to be improved to remove various stratums of governments' special powers to impose taxation.

In GST, consumers should benefit in two ways. First, all taxes collected at the point of consumption. It means that if a trouser is taxed at $18 \%$, it contains both central taxes and state government's taxes. Transparency in taxation should prevent governments from indiscriminately increasing taxes as there is bound to be public repercussion. Second, once barriers between states are removed, we as consumers will not end up paying "tax on tax" which is what occurs when goods move across state boundaries. A uniform GST for the whole nation will assist seamless input tax credit, and thereby exterminate the tax flow effect and the free flow of goods and services across states.

The Goods and Services Tax (GST) replaced various taxes like excise duty, service tax, custom duty, various cesses, local taxes, value added tax, sales tax, entry tax, luxury tax, surcharges etc which are levied by the government.

The government and industry both are engaged strongly in concentrating the various opportunities and challenges in the civil aviation sector; and that's a good welcoming sign. This association needs to be institutionalized and strengthen. With positive monetary factors, low ATF prices and flexi-friendly government policies, India is well placed to attain its vision of becoming the third largest aviation sector by 2020 and the largest by 2030.
GST council has lowered the tax in economy class flight ticket to $5 \%$ from earlier service tax of $6 \%$. However, it increased business class tickets at a GST tax slab of $12 \%$ versus previous service tax of $9 \%$. The government has also levied a GST of $5 \%$ on lease charges paid by various airlines.

Furthermore, airlines can only claim input tax credit (ITC) on its input services for the economy class, while in case of business class they can claim ITC for spare parts, food items and other inputs excluding cost on aviation fuel turbine (ATF) as it falls under purview of the GST.

India's aviation industry is largely intact with enormous growth prospectus, considering that the air travel is still luxurious for the largest part of the country's population. The aviation stakeholders should take on and work in partnership with strategy and policy makers to execute efficient and lucid results that would enhance India's civil aviation industry through proper system, regulations, focusing on passenger satisfaction and overall financial aspects.

\section{Post Implementation effect of GST on key areas in Aviation Sector:}

\section{1) Impact on Air Fares}

According to ICRA's analysis, changes in rates are not a big matter for airline companies and have not any big effect on the air passenger growth. However, the lowering of tax rate on economy class travel is in line with the focus of the Ministry of Civil Aviation to make flying inexpensive for general public class.

\begin{tabular}{|l|c|l|c|}
\hline Economic Class Fare under Service Tax & \multicolumn{2}{|c|}{ Economy class fare under GST regime } \\
\hline Fare/charge & Amount & Fare/charge & Amount \\
\hline Base Fare (Rs) & 3000 & Base Fare & 3000 \\
\hline Airline Fuel Charge & 700 & Airline Fuel Charge & 700 \\
\hline CUTE Charge & 50 & CUTE Charge & 50 \\
\hline Tax and other charges & & Tax and other charges & \\
\hline Passenger Service Fee & 239 & Passenger Service Fee & 239 \\
\hline User Development Fee & 150 & User Development Fee & 150 \\
\hline Airline Service Tax @6\% & 180 & Airline Service Tax @5\% & 150 \\
\hline Other Surcharge & 12 & Other Surcharge & 12 \\
\hline Total & 4331 & Total & 4301 \\
\hline
\end{tabular}

Source: http://www.financialexpress.com/ (July 3, 2017), http://www.zeebiz.com 
Expert analysts Somani Asutosh and Agarwal Nitin from J M Financial expect economy tickets to benefit by $1 \%(6 \%$ to $5 \%)$. However, tickets other than economy to be costlier by $3 \%(9 \%$ to $12 \%)$."

\begin{tabular}{|l|c|l|c|}
\hline Business class fare under Service Tax & Business class fare under GST regime \\
\hline Fare/charge & Amount & Fare/charge & Amount \\
\hline Base Fare (Rs) & 15000 & Base Fare & 15000 \\
\hline Airline Fuel Charge & 2800 & Airline Fuel Charge & 2800 \\
\hline CUTE Charge & 200 & CUTE Charge & 200 \\
\hline Tax and other charges & & Tax and other charges & \\
\hline Passenger Service Fee & 700 & Passenger Service Fee & 700 \\
\hline User Development Fee & 400 & User Development Fee & 400 \\
\hline Airline Service Tax @9\% & 1350 & Airline Service Tax @12\% & 1800 \\
\hline Other Surcharge & 100 & Other Surcharge & 100 \\
\hline Total & 20550 & Total & 21000 \\
\hline
\end{tabular}

Source: http://www.financialexpress.com/ (July 3, 2017), http://www.zeebiz.com

As we know the tax rate for the economy and business class was 6 and $9 \%$ respectively but after implementing the GST, the tax rate on business class airfares is increased up to $12 \%$, whereas, the fares for the economy class reduced up to $5 \%$. These ups and downs in the airfares brought considerable change for the people of India flying across the world.

\section{1) Input cost of Jet Fuel /Aviation Turbine Fuel}

As per the current scenario, GST has affected the aviation sector because petroleum products have been kept out of GST. ATF is highly taxed in quite a few states, so that is bound to affect aviation sector. Given this scenario, airlines tend to take advantage of states that have lower taxes. Further, the government should take the decision on implementing GST on petroleum products such as petrol, diesel and aviation turbine fuel which have been kept out of the GST. The government has decided to keep it out of GST, that means both the Central and the State governments carry on to charge dual taxes on it.

\section{1) Aircraft Leasing}

As a big relief to aviation sector, the import of aircraft on lease is exempted from the Goods and Services Tax (GST). Airlines no need to pay taxes on import of aircraft on lease if the GST is already paid on lease rentals. The government has provided exception from the charges of GST as part of customs duty on the import of aircraft, engines and parts on lease basis from abroad companies. Consequently, GST would only be payable on lease rental payments only. This would bring a great relief to the airline sector by resolving the problem of double levy of GST.

\section{2) Impact on Maintenance, Repair and Overhaul (MRO) Activities:}

The Indian government is considering Maintenance, repair and revision (MRO) as goods and services and both the service tax and VAT were applicable on it. It was assumed that the implementation of GST will reduce the higher cost of both the previous taxation and will decrease the falling effect of taxes. If the aircraft uses service and repair services by abroad or Indian service providers, GST is charged regardless of the place of these services.

\section{3) High Acquiescence Cost}

After the implementation of GST, the registration of the airlines approved by the concern state government. The airline careers also need to provide all the information including flight origination point, the departure point of the flight and location where the registered passenger is located. This new compliance process increased more paperwork with higher acquiescence cost. Furthermore, all the papers and invoices of the departure for registered passengers must be uploaded by the airlines to the online GST portal.

\section{4) GST Implementation on International Flights}

The present tax pattern enforces a service tax on both outgoing and incoming international flight fares. The new tax regime is only levied when the flight begins in India. Further, the GST is imposed on the passengers registered under the GST, regardless of whether the air travel they start, whether it is outgoing or inbounds. If the passengers are not registered under 
the GST, then the return flight fare will be free from the GST.

\section{5) Primary outcome of GST:}

The new GST taxation system affected everyone each and every individual who may be frequent flyer, aviation organization or any stakeholder. GST brought a major change not only in the aviation segment but also other private players of aviation sector. Even if it is likely to enhance the MRO area and the projected increase in cost of fuel has not been justified in a well manner. The aviation sector of India which is already snowed under with high taxation and other related financial burden, it is anticipated that the central government may reevaluate the exclusion of ATF from the GST segment.

\section{CONCLUSION:}

GST on imported aircrafts and its spare parts is not applicable on economy class so it is not adversely affecting the economy class which is the highest source of income for the domestic and international airlines. It has been noticed that the regular flight goers would find GST implementation and the fare of the flights satisfactory. The reduction which took place in the tax system looks to be positive for the regular domestic fliers.

In last, we must say that the aviation sector which is already inundated with high taxation, it is hoped that the central government may reconsider the exclusion of ATF from the GST regime at the earliest to decrease operational cost of Indian airlines.

\section{REFERENCES:}

1. Shaari, Nurulhasni (2015), Student's Awareness and Knowledge on the Implementation of Goods and Services Tax (GST) in Malaysia, International Accounting and Business Conference 2015

2. Jayprakash (2014), Indirect tareforms in India and a way ahead for GST, International Journal of Computing and Corporate Research, ISSN (Online) : 2249-054X, Volume 4 Issue 1 January 2014.

3. Mujade Sakharam (2017), Goods and Service Tax (GST) and its outcome in India, Journal of Madhya Pradesh Economic Association, ISSN 2277-1123, Feb 2017 Vol. XXVII , No. 1
4. Bohrra Monika, (2014), The Goods and Service Tax and its likely impact on Indian Economy, International Journal of Economic Issues, Vol. 7, No. 2 (July-December, 2014)

5. Poddar Satya (2016), EY India Fewer exemptions means greater benefits of GST, The Economic Times, October 2016

6. Sectoral Report Airports | September, 2017,

\section{WEBSITES:}

1. https://www.ibef.org/industry/indian-aviation.aspx

2. www.gstindia.com

3. https://www.ibef.org/industry/indian-aviation.aspx

4. https://cleartax.in/s/impact-of-gst-on-air-fares

5. http://pib.nic.in/newsite/mbErel.aspx?relid=16900 6

6. https://blog.saginfotech.com/gst-impact-onindian-aviation-sector

7. www.economictimes.indiatimes.com/topic/GST

8. www.moneycontrol.com/newstopic/gst

9. www.//en.wikipedia.org/wiki/Goods_and_Service s_Tax_(India).

10. http://bruegel.org/2016/10/goods-and-servicestax-landmark-tax-reforms-in-india/

11. http://indianexpress.com/article/business/economy /gst-rollout-aviation-sector-fully-prepared-for-rollout-on-july-1-jayant-sinha-4712843/

12. http://www.sify.com/finance/gst-issues-foraviation-sector-mostly-resolved-jayant-sinhanews-airlines-rgunkSjbhebdh.html

13. https://home.kpmg.com/in/en/home/media/pressreleases/2016/03/aviation-report-march.htm

14. http://www.financialexpress.com/money/gstimpact-on-air-fare-gst-impact-on-air-ticketsairlines-air-travel-aviation-affected-by-new-taxregime-here-is-how-your-holiday-business-planswill-change/ 746907/

15. http://www.zeebiz.com/india/news-gst-structurefor-airlines-whats-in-store-for-economy-businessclass-and-lease-rentals-18184

16. https://www.gstkeeper.com/gst-impact-onaviation-sector.php 